\title{
PHYSICAL ACTIVITY OF INHABITANTS IN THE CZECH REPUBLIC WITH REGARD TO THEIR EMPLOYMENT
}

\author{
Dagmar Sigmundová, Erik Sigmund, Karel Frömel
}

Faculty of Physical Culture, Palacký University, Olomouc, Czech Republic

Submitted in November, 2012

BACKGROUND: The absence of a paid job has been especially in economically advanced countries associated with a range of negative factors. Unemployment is not only a factor influencing the quality of life but it is also a correlate of physical activity (PA).

OBJECTIVE: The aim of this study is to analyze physical activity in a random sample of inhabitants of the Czech Republic with regard to employment. It focuses not only on total PA but also on PA intensity and its different types.

METHODS: The level of performed PA and its types were assessed using the IPAQ questionnaire, internationally standardized long administrative version of the questionnaire (Craig et al., 2003). The questionnaire estimates PA and sitting done in last seven days and compares PA of vigorous and moderate intensity, walking and sitting in the context with other personal, demographic and environmental factors. The data were gathered in autumn 2007. This study comprises data of 1514 women and 1458 men aged 25-54 years old.

RESULTS: Employed men and women show more vigorous PA and walking than the unemployed. In moderate PA, there are no differences regarding employment and age. PA carried out at home and around the house, and leisure time PA are the same in both employed and unemployed women. Significant differences in total weekly PA between employed and unemployed respondents have been found only in women in the age category of 30-34 years.

CONCLUSIONS: There are no difference in moderate PA regarding employment and age. Significant differences in vigorous PA advocate for involving the unemployed into community service and similar work activities.

Keywords: IPAQ, vigorous PA, leisure time PA, walking.

\section{INTRODUCTION}

Health consequences of low performance of physical activity (PA) have been well documented in literature (Martín, Nieto, Ruiz, \& Jiménez, 2008; World Health Organisation, 2010) and therefore more attention needs to be paid to individual correlates that influence it. Among these correlates, we can find employment, or unemployment, of the inhabitants which can be an obstacle in PA performance (Van Domelen et al., 2011). Lack of time is the most frequently stated barrier to PA performance (McKenna, Naylor, \& McDowell, 1998; Reichert, Barros, Domingues, \& Hallal, 2007). Therefore, we could assume that the unemployed have better conditions regarding time to perform PA. Are unemployed people really more physically active than those with a paid job? Involuntary employment worsens both physical and mental health (Kessler, Turner, $\&$ House, 1988). Unemployed people usually fell into the unhealthy in psychological and behavioral categories, and unemployed people reported adverse health behaviors as compared to those employed full-time (Rosenthal, Carroll-Scott, Earnshaw, Santilli, \& Ickovics, 2012). Previous research shows, that common lifestyle risk factors (like smoking, alcohol intake, low physical activity) are higher among the unemployed adult population (Schuit, van Loon, Tijhuis, \& Ocké, 2002). Besides, unemployed people have significantly higher odds of low leisure-time physical activity (Mohammad Ali \& Lindström, 2006).

In unemployed people or people less active at work, there has been a greater occurrence of overweight and obesity found (Martín et al., 2008; Rhodes, Mark, \& Temmel, 2012). On the other hand, people more active around their job tend to be more satisfied with their mental wellbeing, their sexual and social life than people without a job (Melin, Fugl-Meyer, \& Fugl-Meyer, 2003). In terms of realization of physical activity, sport participation is related to less distress in unemployed adults (Asztalos et al., 2009). Another important point in physical activity through life is the retirement. Results from Health and Retirement Study shows that physical activity decreased with retirement from a physical demanding job, but increased with retirement from a sedentary job (Chung, Domino, Stearns, \& Popkin, 2009).

In the Czech Republic (CZ), the average rate of unemployment was $6.5 \%$ (Český statistický úr̆ad, 2008) 
in 2007 when the collection of data was carried out. Unemployment has been rising since then. In 2011, the average unemployment rate in $\mathrm{CZ}$ was $8.6 \%$ (Český statistický úřad, 2012).

Recommendations as well as effective intervention physical activity programs should be based on a standardized tool to assess the level of PA as well as its types and intensity in different context (Abu-Omar, Rütten, \& Robine, 2004). The internationally standardized IPAQ questionnaire - "International Physical Activity Questionnaire" is such a tool which allows international comparisons and identifies PA correlates.

The aim of this study is to analyze PA in a random sample of the inhabitants in the Czech Republic with the regard to their status of employment. Specific aims are:

- to analyze PA regarding daily activities between the employed and the unemployed respondents;

- to analyze PA regarding its intensity between the employed and the unemployed respondents.

\section{METHODS}

The participants in the study were aged 25-54 years. In order to minimize the influence of specific groups regarding the factor of employment, university students and pensioners were not included in the analysis of the sample. Basic somatic characteristics of the sample are stated in TABLE 1.

The number of employed men in individual age categories ranges from $2.5 \%$ to $8 \%$, in women, it is from
$6 \%$ to $28 \%$. On the average, there were $5.2 \%$ of men and $14 \%$ of women unemployed among the participants.

The survey was a part of nationwide research of PA, which is a part of international research (International Physical Activity Questionnaire Prevalence Study; www.ipaq.ki.se). The level of performed PA and its levels were estimated using the IPAQ questionnaire, the internationally standardized long version (Craig et al., 2003). The questionnaire estimates PA and time spent sitting in last seven days and allows to compare PA of vigorous and moderate activity, walking and sitting in associations with different personal, demographic and environmental data.

The data were collected in autumn 2007. The questionnaires were distributed stratified in each region. There were data by 1514 women and 1458 men aged 25-54 included into the study who completed fully and correctly the IPAQ questionnaires with a clearly stated status of having a paid job (or without a paid job) in the time of the study. The identification of the profession was not part of the study.

The data were adjusted in compliance with the international guidelines for data processing as stated by the "IPAQ Research Committee" (www.ipaq.ki.se). The evaluation of physical activity in MET was 6 METs for vigorous PA, 3-6 METs for moderate PA - according to its type and 3.3 METs for walking. The total average PA in MET-minutes/week was calculated using average minute values of a given PA (vigorous, moderate intensity, walking) multiplied by a responding energy equivalent in METs for a given PA intensity. The sum of values in MET-minutes/week for vigorous, moderate PA and walking equaled the total PA level.

\section{TABLE 1}

Basic somatic characteristics of the sample

\begin{tabular}{|l|c|c|c|c|c|}
\hline \multirow{4}{*}{ Gender } & Age group & $\boldsymbol{n}$ & $\begin{array}{c}\text { Weight }[\mathbf{k g}] \\
\text { M (SD) }\end{array}$ & $\begin{array}{c}\text { Height }[\mathbf{c m}] \\
\text { M (SD) }\end{array}$ & $\begin{array}{c}\left.\text { BMI [kg } \times \mathbf{~ m}^{-2}\right] \\
\text { M (SD) }\end{array}$ \\
\hline \multirow{4}{*}{ Male } & $\mathbf{2 5 - 2 9}$ & 276 & $81.53(11.38)$ & $181.51(6.76)$ & $24.69(2.79)$ \\
\cline { 2 - 6 } & $\mathbf{3 0 - 3 4}$ & 240 & $84.25(12.14)$ & $180.99(7.80)$ & $25.66(2.96)$ \\
\cline { 2 - 6 } & $\mathbf{3 5 - 3 9}$ & 205 & $85.02(11.19)$ & $180.47(7.36)$ & $26.10(3.05)$ \\
\cline { 2 - 6 } & $\mathbf{4 0 - 4 4}$ & 228 & $86.64(11.51)$ & $180.08(6.99)$ & $26.69(2.98)$ \\
\cline { 2 - 6 } & $\mathbf{4 5 - 4 9}$ & 241 & $86.88(11.26)$ & $180.01(6.91)$ & $26.79(2.98)$ \\
\cline { 2 - 6 } & $\mathbf{5 0 - 5 4}$ & 299 & $87.64(12.04)$ & $179.62(6.93)$ & $27.14(3.22)$ \\
\hline \multirow{4}{*}{ Female } & $\mathbf{2 5 - 2 9}$ & 229 & $62.50(10.01)$ & $168.58(6.08)$ & $21.96(3.08)$ \\
\cline { 2 - 6 } & $\mathbf{3 0 - 3 4}$ & 242 & $63.83(9.20)$ & $168.71(6.03)$ & $22.41(2.93)$ \\
\cline { 2 - 6 } & $\mathbf{3 5 - 3 9}$ & 275 & $65.21(10.25)$ & $167.59(6.04)$ & $23.24(3.56)$ \\
\cline { 2 - 6 } & $\mathbf{4 0 - 4 4}$ & 327 & $65.76(10.04)$ & $166.62(5.87)$ & $23.70(3.55)$ \\
\cline { 2 - 6 } & $\mathbf{4 5 - 4 9}$ & 251 & $67.94(10.65)$ & $166.37(5.73)$ & $24.56(3.76)$ \\
\cline { 2 - 6 } & $\mathbf{5 0 - 5 4}$ & 216 & $69.26(11.10)$ & $165.77(6.65)$ & $25.22(3.99)$ \\
\hline
\end{tabular}

Legend: M - mean, SD - standard deviation, BMI - body mass index 
In order to assess significant differences, we applied the variance analysis, non-parametric Kruskal-Wallis test and responding effect size $\eta^{2}$ coefficient. The values of the size $\eta^{2}$ coefficient can be interpreted in this way: $\eta^{2} \in\left(0.01-0.06>\right.$ small effect, $\eta^{2} \in(0.06-0.14>$ moderate effect a $\eta^{2}>0.14$ large effect (Morse, 1999). The associations between physical activity and employment were assessed using the Spearman correlation coefficient $r_{\text {sp }}$. An alpha level of 0.05 was set to evaluate statistical significance.

\section{RESULTS}

The most significant differences have been found in vigorous PA in favor of employed women $\left(\mathrm{H}(1,1514)=51.37 ; p<0.001 ; \eta^{2}=0.03\right)$. These differences ranged between 900-1100 MET-minutes/ week (Fig. 1). In walking, there was a difference of 644 MET-minutes/week in the age category of 30-34. There were, however, more significant differences found in women aged 45-49 or 50-54 with differences of 883 MET-minutes/week or 654 MET-minutes/week respectively. Regardless of the age category, employed women showed significantly more walking $\left(\mathrm{H}(1,1514)=5.43 ; p=0.02 ; \eta^{2}=0.003\right)$ than unemployed women although the effect size coefficient did not confirm this significance. In case of PA of moderate intensity, it is similar to walking $\left(\mathrm{H}(1,1514)=5.38 ; p=0.02 ; \eta^{2}=0.004\right)$.

Concerning inactivity, both men and women spend on average 320-390 minutes a day sitting, or sitting or standing in a motor vehicle. Employed men ( $\mathrm{M}=64.4 \mathrm{~min} . /$ day) spend on average 16 minutes more in a motor vehicle than unemployed men and about twice as much time than employed women $(\mathrm{M}=38$ min./day) or unemployed women $(\mathrm{M}=32.8 \mathrm{~min}$./day $)$. Overall, differences in sitting between employed and unemployed men are not significant. It is the opposite in women. Employed women showed significantly more sitting than unemployed women $(\mathrm{H}(1,1514)=9.88$; $p=0.002$ ).

Next to job related PA, we have found differences between employed and unemployed women in PA in transport from a place to place $(\mathrm{H}(1,1514)=9.76$; $p=0.002)$ in favor of the unemployed. On the other hand, employment does not influence leisure time PA in women and house related PA; both are similar. We need to stress that unemployed women showed mainly less vigorous PA. Other than job-related PA is higher than in the employed women. Yet, it does not exceed the total PA level in any age category in employed women.

There are differences in age categories of 25-29 $(p=0.01)$ and $40-44(p=0.02)$ in leisure time PA between employed and unemployed women (Fig. 2). In the age category of 25-29 years, it was in favor of employed women, in the age category of 40-44 unemployed women showed more leisure time PA.

Since the percentage representation of men without a paid job was low, the comparison of PA between individual age categories was not relevant.

There were differences between employed and unemployed men in walking and vigorous PA (TABLE 2),

Fig. 1

Structure of physical activity in employed and unemployed women with regard to its intensity and age category

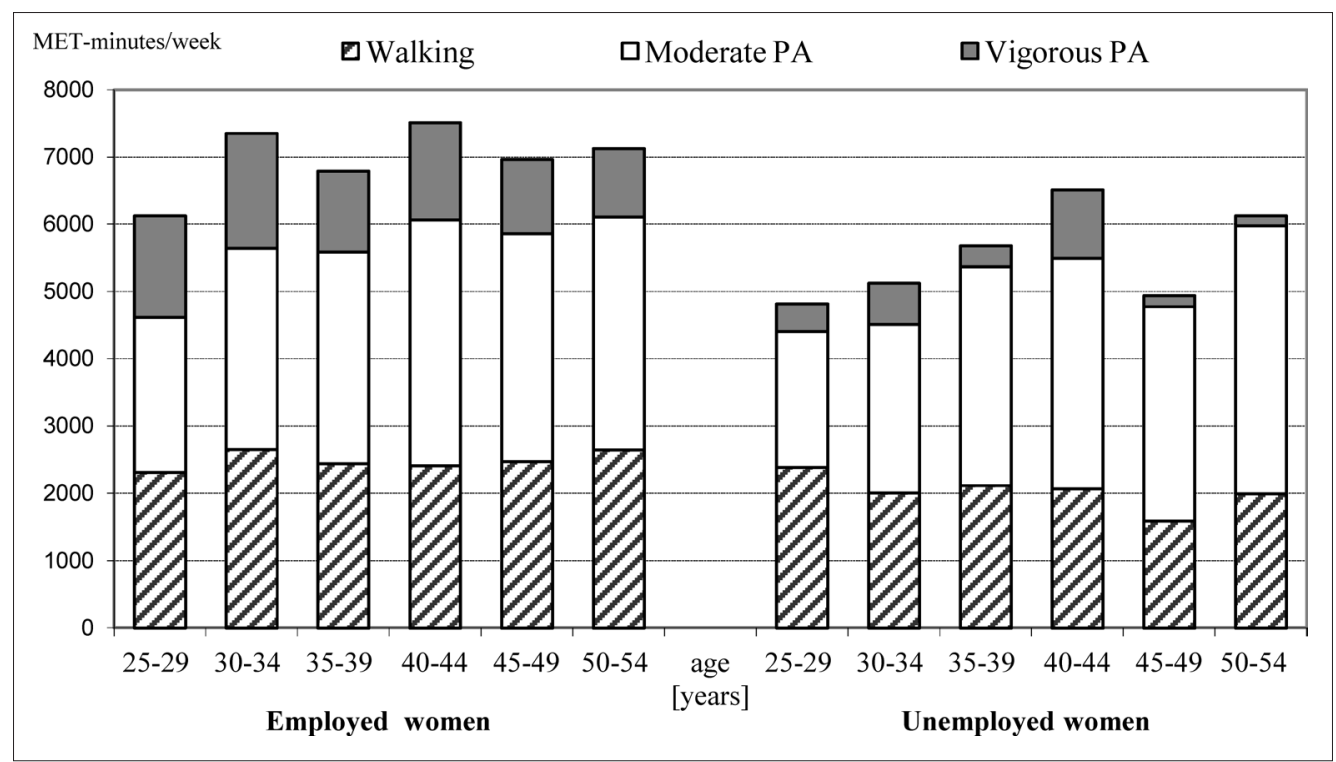


Fig. 2

Structure of weekly physical activity in employed and unemployed women

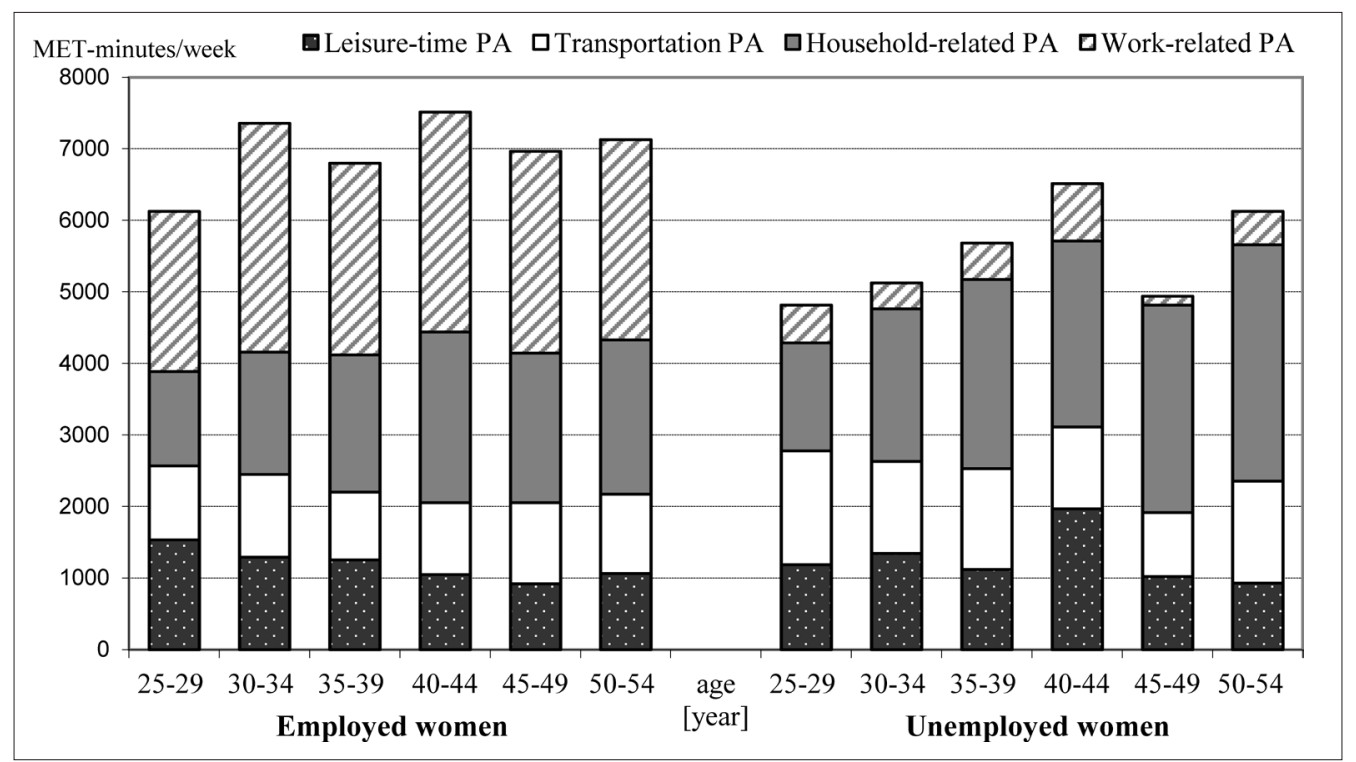

TABLE 2

Differences between physical activity in employed $(n=1383)$ and unemployed men $(n=75)$

\begin{tabular}{|c|c|c|c|c|c|c|}
\hline $\mathbf{P A}$ & Status & Mdn & IQR & $\mathbf{H}$ & $p$ & $\eta^{2}$ \\
\hline \multirow{2}{*}{ Walking } & Employed & 1518 & 2871 & \multirow{2}{*}{5.16} & \multirow{2}{*}{0.02} & \multirow{2}{*}{0.004} \\
\hline & Unemployed & 1188 & 2079 & & & \\
\hline \multirow{2}{*}{ Moderate PA } & Employed & 2400 & 3750 & \multirow{2}{*}{1.79} & \multirow{2}{*}{0.18} & \multirow{2}{*}{ - } \\
\hline & Unemployed & 2140 & 3085 & & & \\
\hline \multirow{2}{*}{ Vigorous PA } & Employed & 1200 & 3960 & \multirow{2}{*}{8.85} & \multirow{2}{*}{0.003} & \multirow{2}{*}{0.006} \\
\hline & Unemployed & 720 & 2700 & & & \\
\hline
\end{tabular}

Legend: PA - physical activity, Mdn - median, IQR - inter-quartile range, H - Kruskal-Wallis test, $\eta^{2}$ - effect size, $p$ - significance value, significant values are in bold

but also in leisure time PA $(p=0.004)$ with results in favor of men without a paid job.

Concerning the participation in organized PA, 63\% of employed participants stated they participated in organized PA. This fact is stated by $69 \%$ of unemployed respondents.

Employment correlates positively with job-related PA $r_{\mathrm{sp}}=0.304$ and also with vigorous PA $r_{\mathrm{sp}}=0.165$. Overall, there were statistically significant differences in weekly PA (total PA) only between employed and unemployed women in the age category of $30-34(\mathrm{H}(1,234)=7.57$, $p=0.006)$.

\section{DISCUSSION}

The aim of this study was to analyze different types of PA and different PA intensities with the regard to employment status. The absence of a paid job is especially in economically advanced countries associated with a number of negative factors. Unemployment, next to being a factor influencing quality of life standards, is also perceived negatively in terms of one's personal dignity and self-respect (Katrnak \& Mares, 2007). With increasing length of unemployment, the risk of overweight and obesity increases (Martín et al., 2008). Majority of the unemployed perceive the loss of a job as a loss of their life security and disturbance to their lifestyle. There exists also mental-health related selection effects during job loss and job search, but they are weak (Wanberg, 2012). Mental health seemed to be impacted by the source of unemployment, voluntary versus involuntary, with those who were voluntarily unemployed having mental health scores similar to those who were employed (Pharr, Moonie, \& Bungum, 2012). Moreover, after more than a half of year of unemployment, 
there are negative mental health issues, and the unemployed tend to satisfy their mental and social needs with more difficulties (Chobotová, Šlachová, Tomášková, \& Šplíchalová, 2003). They lose their PA patterns associated with the work routine and show higher risk of a low subjective health assessment (Kaleta, MakowiecDąbrowska, \& Jegier, 2008). The accumulation of the socio-economical disadvantages is associated with a low performance of PA or its complete absence (Popham $\&$ Mitchell, 2007). Yet, also unemployed people often perform low PA (Juneau \& Potvin, 2010).

In people with vocational, or otherwise physically demanding professions, there especially might be a lack of leisure time PA (Burton \& Turrell, 2000; Tigbe, Lean, \& Granat, 2011), however the overall PA does not have to be unsatisfactory. Nevertheless, this study similarly to other international studies (Van Domelen et al., 2011) shows that the unemployed perform less PA than those employed. There are differences in the area of PA intensity, when there is almost missing vigorous PA in the group of the unemployed. The regional results IPAQ study in the Czech Republic shows lower chances of the unemployed adults to meet recommendations for moderate to vigorous PA (Bláha \& Frömel, 2011). Due to low number of unemployed men in this study, the analysis for different age categories was omitted. Yet, the total results show that both unemployed men and women show less walking. Since the environment in the Czech Republic is considered a walking one (Frömel et al., 2006), the enhancement of walking in leisure time is important. Walking as basic locomotion is not influenced by residential density (Frömel, Mitáš, \& Kerr, 2009) and it should be enhanced in all age groups. The amount of income could be also essential, which is low in case of the unemployed, yet it is not the most significant factor. Unemployment if often associated with poverty in the European Union, the same applies to the Czech Republic (Katrnak \& Mares, 2007). Unemployment impacts also family relations and influences also other social activities (Chobotová et al., 2003), which become restricted due to financial reasons. Regarding PA, in a study of 1818 adult Americans, the participants confirmed that as for individual levels of PA the amount of income is important, however not as important at the neighborhood (Parks, Housemann, \& Brownson, 2003).

It is apparent that people without a paid job, although they have more free time, are not more physically active. In some cases, their leisure time PA is higher than in the employed one, but in total it cannot compensate job-related PA.

There are limits to this study. The study included people who in the questionnaire indicate that they do not have a paid job, this classification was subjective. Professions neither the length of unemployment were asked about. Previous studies have shown that seasons influence PA (Chan, Ryan, \& Tudor-Locke, 2006; McCormack, Friedenreich, Shiell, Giles-Corti, \& DoyleBaker, 2010; Plasqui \& Westerterp, 2004), and this study was carried out in autumn when PA is lower than in summer due to the weather (McCormack et al., 2010).

\section{CONCLUSIONS}

Employed men and women show more vigorous PA and walking than the unemployed. PA in women in house and around the house and leisure time physical activity is the same in both the employed and unemployed women. There were no significant differences found between employed and unemployed men in PA in house and around the house nor in transportation PA. There are no difference in moderate PA regarding employment and age. Employed men spend more than an hour a day sitting (standing) in a motor vehicle, unemployed by a quarter of time less. Unemployed women show more active transportation (walking, cycling) than employed women.

Although employed people show more PA, PA could be still enhanced also by employers as it is common in economically advanced countries. For example by incorporating physical activity recesses, or by supporting organized PA in working hours. There is significant lack of PA in active transportation of different types.

\section{ACKNOWLEDGEMENT}

The study has been supported by the research grant from the Ministry of Education, Youth and Sports of the Czech Republic (No. MSM 6198959221) "Physical activity and inactivity of the inhabitants of the Czech Republic in the context of behavioral changes".

This paper was supported by the ECOP project, "Strengthening scientific potential of the research teams in promoting physical activity at Palacký University," reg. No. CZ.1.07/2.3.00/20.0171.

\section{REFERENCES}

Abu-Omar, K., Rütten, A., \& Robine, J. M. (2004). Self-rated health and physical activity in the European Union. Sozial und Präventivmedizin, 49(4), 235-242.

Asztalos, M., Wijndaele, K., De Bourdeaudhuij, I., Philippaerts, R., Matton, L., Duvigneaud, N., et al. (2009). Specific associations between types of physical activity and components of mental health. Journal of Science and Medicine in Sport, 12(4), 468-474. 
Bláha, L., \& Frömel, K. (2011). Pohybová aktivita 25-57letých obyvatel Ústeckého kraje z aspektu zaměstnanosti. Tělesná kultura, 34(1), 93-106.

Burton, N. W., \& Turrell, G. (2000). Occupation, hours worked, and leisure-time physical activity. Preventive Medicine, 31(6), 673-681.

Craig, C. L., Marshall, A. L., Sjostrom, M., Bauman, A. E., Booth, M. L., Ainsworth, B. E., et al. (2003). International physical activity questionnaire: 12 country reliability and validity. Medicine and Science in Sports and Exercise, 35(8), 1381-1395.

Český statistický úřad. (2008). Zaměstnanost a nezaměstnanost $v \check{C} R$ podle výsledkủ výberrového šetrení pracovních sil - roční průměry 2007. Retrieved 26. 9. 2008 from the World Wide Web: http://www. czso.cz/CSU/2008edicniplan.nsf/p/3115-08

Český statistický úřad. (2012). Statistická ročenka České republiky 2012. Retrieved 10. 1. 2013 from the World Wide Web: http://www.czso.cz/csu/2012edicniplan. nsf/p/0001-12

Frömel, K., Bauman, A., Bláha, L., Feltlová, D., Fojtík, I., Hájek, J., et al. (2006). Intenzita a objem pohybové aktivity 15-69leté populace České republiky. Česká kinantropologie, 10(1), 13-27.

Frömel, K., Mitáš, J., \& Kerr, J. (2009). The associations between active lifestyle, the size of a community and SES of the adult population in the Czech Republic. Health and Place, 15(2), 447-454.

Chan, C., Ryan, D., \& Tudor-Locke, C. E. (2006). Relationship between objective measures of physical activity and weather: A longitudinal study. International Journal of Behavioral Nutrition and Physical Activity, 3(1), 21.

Chobotová, P., Šlachová, H., Tomášková, H., \& Šplíchalová, A. (2003). Nezaměstnanost a zdraví. Retrieved 31. 10. 2008 from the World Wide Web: http://zuova.cz/projekty/nezam/strba-sbornik.pdf

Chung, S., Domino, M. E., Stearns, S. C., \& Popkin, B. M. (2009). Retirement and physical activity: Analyses by occupation and wealth. American Journal of Preventive Medicine, 36(5), 422-428.

Juneau, C. E., \& Potvin, L. (2010). Trends in leisure, transport, and work-related physical activity in Canada 1994-2005. Preventive Medicine, 51(5), 384-386.

Kaleta, D., Makowiec-Dąbrowska, T., \& Jegier, A. (2008). Employment status and self rated health. International Journal of Occupational Medicine and Environmental Health, 21(3), 227-236.

Katrnak, T., \& Mares, P. (2007). Segmenty zaměstnaných a nezaměstnaných v České republice v letech 1998 až 2004 (The employed and the unemployed in the Czech labour market between 1998 and 2004). Sociologický časopis, 43(2), 281-303.

Kessler, R. C., Turner, J. B., \& House, J. S. (1988). Effects of unemployment on health in a communi- ty survey: Main, modifying, and mediating effects. Journal of Social Issues, 44(4), 69-85.

Martín, A. R., Nieto, J. M. M., Ruiz, J. P. N., \& Jiménez, L. E. (2008). Overweight and obesity: The role of education, employment and income in Spanish adults. Appetite, 51(2), 266-272.

McCormack, G. R., Friedenreich, C., Shiell, A., Giles-Corti, B., \& Doyle-Baker, P. K. (2010). Sex and age-specific seasonal variations in physical activity among adults. Journal of Epidemiology and Community Health, 64(11), 1010-1016.

McKenna, J., Naylor, P. J., \& McDowell, N. (1998). Barriers to physical activity promotion by general practitioners and practice nurses. British Journal of Sports Medicine, 32(3), 242-247.

Melin, R., Fugl-Meyer, K. S., \& Fugl-Meyer, A. R. (2003). Life satisfaction in 18 to 64 year old Swedes: In relation to education, employment situation, health and physical activity. Journal of Rehabilitation Medicine, 35(2), 84-90.

Mohammad Ali, S., \& Lindström, M. (2006). Psychosocial work conditions, unemployment, and leisuretime physical activity: A population-based study. Scandinavian Journal of Public Health, 34(2), 209216.

Morse, D. T. (1999). MINSIZE2: A computer program for determining effect size and minimum sample size for statistical significance for univariate, multivariate, and nonparametric tests. Educational and Psychological Measurement, 59(3), 518-531.

Parks, S. E., Housemann, R. A., \& Brownson, R. C. (2003). Differential correlates of physical activity in urban and rural adults of various socioeconomic backgrounds in the United States. Journal of Epidemiology and Community Health, 57(1), 29-35.

Pharr, J. R., Moonie, S., \& Bungum, T. J. (2012). The impact of unemployment on mental and physical health, access to health care and health risk behaviors. ISRN Public Health, 2012, 7. doi:10.5402/2012/483432

Plasqui, G., \& Westerterp, K. R. (2004). Seasonal variation in total energy expenditure and physical activity in Dutch young adults. Obesity Research, 12(4), 688-694.

Popham, F., \& Mitchell, R. (2007). Relation of employment status to socioeconomic position and physical activity types. Preventive Medicine, 45(2-3), 182188.

Reichert, F. F., Barros, A. J. D., Domingues, M. R., \& Hallal, P. C. (2007). The role of perceived personal barriers to engagement in leisure-time physical activity. American Journal of Public Health, 97(3), 515-519.

Rhodes, R. E., Mark, R. S., \& Temmel, C. P. (2012). Adult sedentary behavior: A systematic review. American Journal of Preventive Medicine, 42(3), 3-28. 
Rosenthal, L., Carroll-Scott, A., Earnshaw, V. A., Santilli, A., \& Ickovics, J. R. (2012). The importance of full-time work for urban adults' mental and physical health. Social Science \& Medicine, 75(9), 1692-1696.

Schuit, A. J., van Loon, A. J. M., Tijhuis, M., \& Ocké, M. C. (2002). Clustering of lifestyle risk factors in a general adult population. Preventive Medicine, 35(3), 219-224.

Tigbe, W. W., Lean, M. E. J., \& Granat, M. H. (2011). A physically active occupation does not result in compensatory inactivity during out-of-work hours. Preventive Medicine, 53(1-2), 48-52.

Van Domelen, D. R., Koster, A., Caserotti, P., Brychta, R. J., Chen, K. Y., McClain, J. J., et al. (2011). Employment and physical activity in the U.S. American Journal of Preventive Medicine, 41(2), 136-145.

Wanberg, C. R. (2012). The individual experience of unemployment. Annual Review of Psychology, 63, 369-396.

World Health Organisation. (2010). Global recommendations on physical activity for health. Geneva, Switzerland: WHO Press.

\section{POHYBOVÁ AKTIVITA OBYVATEL ČESKÉ REPUBLIKY S OHLEDEM NA JEJICH ZAMĚSTNANOST}

(Souhrn anglického textu)

VÝCHODISKA: Absence placeného zaměstnání bývá zejména $\mathrm{v}$ ekonomicky vyspělých zemí spojována $\mathrm{s}$ řadou negativních faktorů. Nezaměstnanost je nejenom faktor ovlivňující životní úroveň, ale je i korelátem pohybové aktivity (PA).

CÍLE: Cílem této práce je analyzovat pohybovou aktivitu u randomizovaného souboru obyvatel ČR vzhledem $\mathrm{k}$ jejich statusu zaměstnanosti. Zaměřit se nejen na celkovou PA, ale i na intenzitu PA a na její jednotlivé druhy.

METODIKA: Úroveň realizované PA a její druhy byly stanovovány z IPAQ dotazníku, mezinárodně standardizované dlouhé administrativní verzi (Craig et al., 2003). Dotazník zachycuje PA a sezení realizované v posledních sedmi dnech a umožňuje srovnávat PA vysoké a střední intenzity, chůzi i sezení v kontextu s dalšími personálními, demografickými a environmentálními údaji. Data byla shromážděna na podzim roku 2007. Do této studie jsou zahrnuta data od 1514 žen a 1458 mužů ve věku 25-54 let.

VÝSLEDKY: Zaměstnaní muži i ženy vykazují více intenzivní PA a chůze než nezaměstnaní. Ve středně intenzivní PA jsme nenalezli rozdíly z hlediska zaměstnanosti a věku. PA realizovaná uvnitř a okolo domu i volnočasová PA je mezi zaměstnanými a nezaměstnanými ženami srovnatelná. Signifikantní rozdíly v celkové týdenní PA mezi zaměstnanými a nezaměstnanými respondenty byly nalezeny pouze u žen ve věkové kategorii 30-34 let.

ZÁVĚRY: Kromě žen ve věku 30-34 let nebyly nalezeny rozdíly v PA mezi zaměstnanými a nezaměstnanými muži i ženami. Významné rozdíly v intenzivní PA podporují snahy o zapojování nezaměstnaných do veřejných prací a podobných pracovních aktivit.

Klićcová slova: IPAQ, intenzivní PA, volnočasová PA, chůze.

\section{Mgr. Dagmar Sigmundová, Ph.D.}

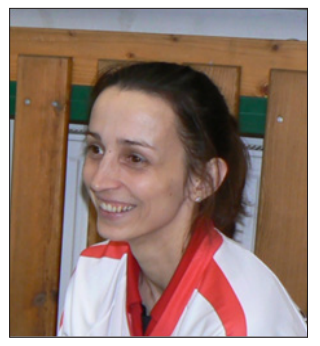

Palacký University, Olomouc

Faculty of Physical Culture

tř. Míru 115

77111 Olomouc

Czech Republic

Education and previous work experience

Since 2011 - Member of the Czech HBSC team.

Since 2005 - Research and Academic Worker, Center for Kinanthropology Research, Palacký University in Olomouc.

2005 - Ph.D. in Kinanthropology.

Dr. Sigmundová is a research worker at the FPC UP, a member of the Czech Kinanthropology Society. She specializes in statistical analysis of data and terrain monitoring of physical activity in children, youth, and adults. Next scientific interests are in the trends of physical activity and obesity, parents' involvement in children's physical activity, leisure time and extracurricular activities of children and adolescents.

\section{First-line publications}

She has published 8 papers in impact journals (WOS) and over 30 papers in conference proceedings and other journals. 